\title{
Article
}

\section{Impact of pharmacy medicine information service advice on clinician and patient outcomes: an overview}

\author{
Rutter, Jill and Rutter, Paul \\ Available at http://clok.uclan.ac.uk/30334/ \\ Rutter, Jill and Rutter, Paul ORCID: 0000-0003-4106-1515 (2019) Impact of \\ pharmacy medicine information service advice on clinician and patient \\ outcomes: an overview. Health Information \& Libraries Journal, 36 (4). pp. \\ 299-317. ISSN 1471-1834
}

It is advisable to refer to the publisher's version if you intend to cite from the work. http://dx.doi.org/10.1111/hir.12270

For more information about UCLan's research in this area go to http://www.uclan.ac.uk/researchgroups/ and search for < name of research Group>.

For information about Research generally at UCLan please go to http://www.uclan.ac.uk/research/

All outputs in CLoK are protected by Intellectual Property Rights law, including Copyright law. Copyright, IPR and Moral Rights for the works on this site are retained by the individual authors and/or other copyright owners. Terms and conditions for use of this material are defined in the policies page.

\section{CLoK}

Central Lancashire online Knowledge www.clok.uclan.ac.uk

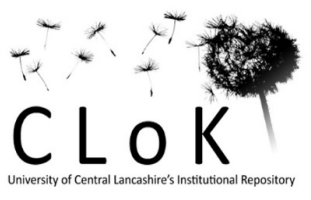


Impact of Pharmacy Medicine Information Service Advice on Clinician and

Patient Outcomes: an overview

Running title: Impact of MI advice

Author Information

Jill Rutter MSc ${ }^{1}$, Paul Rutter PhD (ORCID No: 0000-0003-4106-1515)

${ }^{1}$ PhD student, Pharmacy Department, Faculty of Science and Engineering,

University of Wolverhampton, Wolverhampton, UK.

${ }^{2}$ Professor of Pharmacy, School of Pharmacy and Biomedical Sciences, Faculty of

Clinical and Biomedical Sciences, University of Central Lancashire, Preston, UK.

Acknowledgements: None

Conflict of interest: None

Source of funding: None

Correspondence

Mrs Jill Rutter

UK

Tel: 07777607214

E-mail: jill.rutter2@wlv.ac.uk 


\title{
Impact of Pharmacy Medicine Information Service Advice on Clinician and Patient Outcomes: an overview
}

\begin{abstract}
Background

Pharmacy-led medicine information (MI) services are available in many countries to support clinicians and patients make decisions on use of medicines.
\end{abstract}

Objectives

To establish what impact, if any, pharmacy-led MI services have on clinician and patient outcomes.

Methods

All published works indexed in Embase or PubMed, meeting this review's inclusion and exclusion criteria, that wholly or partially attempted to measure the effects of $\mathrm{Ml}$ advice were retrieved and assessed.

Results

Twenty studies were reviewed. Five broad themes were identified describing study findings, three were specific to clinicians: their views on the effect MI answers had; actions they took; and influence on their decision-making. A fourth theme centred on patient utilisation of advice, and the fifth on 'process measures' attempting to determine MI worth.

\section{Discussion}

Studies report on positive patient outcomes as a direct result of MI advice. Clinicians and patients acted upon the advice provided. Clinicians also reported using MI advice as a 'safety net', to check, reassure or confirm what to do. MI advice also demonstrated economic worth, although these studies are old.

Conclusion

MI Service advice appears to effect clinician and patient outcomes. However, study design limitations require findings be viewed cautiously.

\section{Key messages}

Findings suggest that $\mathrm{Ml}$ advice does effect patient outcome but establishing the full clinical and economic impact this has on patient care requires further investigation.

MI advice positively effects clinicians suggested by their use of the service as a 'safety net', to check, reassure or confirm what to do for their patients. 
Future research evaluations should consider collaboration with clinical library services as both serve a similar client base and have common goals.

\section{Introduction}

Advances in medical treatment mean people are now living longer, often with comorbidities, which require complex polypharmacy intervention. It is therefore not surprising that medicines are the commonest healthcare intervention (Prescribing and Medicines Team, 2017). Furthermore, medicines are constantly brought to market, for example in 2016 the European Medicines Agency approved 81 medicines, 27 of which were new active substances (European Medicines Agency, 2017). This makes it challenging for clinicians to keep up-to-date given the high volume of constantly changing information about medicines (Clarke et al., 2013). It is acknowledged that medically qualified clinicians receive little formal training in prescribing and lack confidence in searching or appraising the large amount of information available to them (Bernard et al., 2012; Bourne 2007; Clarke et al., 2013; Damarell \& Tieman, 2015; Davidoff et al., 1995; Iqbal \& Glenny, 2002; Zwolsman 2012).

Pharmacy-led medicine information (MI) services are available as a resource for clinicians (and patients) in some countries to help them answer medicine-related questions. Historically, most published MI studies have focused on service evaluation, mainly utilising quantitative, self-administered questionnaires to establish user satisfaction (Bertsche et al., 2007; Fathelrahman et al., 2008; Hedegaard \& Damkier, 2009; McEntee et al., 2010; Maywald et al., 2004; Melnyk et al., 2000; Repchinsky \& Masuhara, 1987; Schjøtt \& Gedda-Dahl, 2002). Overall, clinician and patient satisfaction has tended to be high. Papers assessed this on the usefulness of the advice provided through a variety of measures including, speed of response (Maywald et al., 2004); timeliness (Hedegaard \& Damkier, 2009; Melnyk et al., 2000 Schjøtt et al., 2002); objectivity (Melnyk et al., 2000); comprehensiveness (Hedegaard \& Damkier, 2009); adequacy and/or relevance of the answer (Maywald et al., 2004) and value of the references included with the answer (Schjøtt et al., 2002).

Early MI papers were also subject to two reviews (Hands et al., 2002; Spinewine \& Dean, 2002). Hands et al aimed to establish clinical and economic impact of MI services on patients'. Seven studies were included (six published articles and one unpublished document), in which Hands et al concluded favourable impact was reported in some studies but questioned the validity of their findings due to methodological limitations. Spinewine and Dean appraised nine papers, including three of the same papers by Hands to assess impact on patient outcome of passive information given to healthcare professionals by MI services (Spinewine \& Dean, 2002). The authors, like Hands et al, questioned methodological rigour of the studies and therefore their findings. In summary, both reviews were critical of the measures used and called for further studies to be conducted that were more robustly designed to allow outcome or impact to be better assessed.

Whilst further studies on user satisfaction have been conducted, MI researchers have begun to focus more on outcome and impact as advocated by the two reviews, especially given that Western healthcare is now more outcome driven. This review 
therefore attempts to assess $\mathrm{MI}$ research where outcome and/or impact has featured in data, whether as the major objective of authors or as an element of their work.

\section{Method}

We searched Embase $\AA$ and PubMed $\AA$ databases from their respective start dates to February 2019 for original English language research articles (journals and conference proceedings only), spanning both primary and secondary care that attempted to measure the outcomes of $\mathrm{Ml}$ advice. Those papers from the two reviews that met our criteria for inclusion were considered. A range of search terms were used and reproduced in Table 1 . In addition, reference lists from those articles identified as relevant were searched and any papers deemed appropriate were also reviewed. Papers were excluded if they only evaluated user satisfaction of MI services or other aspects of $\mathrm{Ml}$ work, including those studies which assessed theoretical impact or avoidance of harm. Papers were screened and reviewed independently against the above inclusion and exclusion criteria by the first author (JR).

Data from the included studies was entered into Microsoft Excel v. 16.0 (Microsoft Corporation, Redmond, United States of America). The data included: (i) author; (ii) year of publication; (iii) study country; (iv) aims; (v) study design, method and sample size; (vi) outcome measures. All data relating to descriptions around impact and outcome were assessed and categorised into themes.

\section{Results}

The literature search identified 1631 articles, of which 156 were MI papers with 20 eligible for inclusion (Figure 1). A summary of each paper is shown in Table 2, with data extracted and collated in Table 3, under geographic location, when published, type and nature of study, population studied and work setting of clinician.

The majority of studies sampled clinicians $(n=15)$, five of which specifically targeted prescribers (doctors and dentists) (Frost Widnes \& Schjøtt, 2009; Hedegaard \& Damkier, 2009; Rutter et al., 2015; Schjøtt et al., 2002; Strobach et al., 2015). A large proportion of clinicians in the non-prescriber studies were pharmacists, ranging from 28 to $95 \%$ (Bertsche et al., 2007; Stubbington et al., 1998). Four studies targeted the public/patients with a further study seeking the views from both clinicians and the public (Badiani et al., 2017; Bramley et al., 2018; Joseph \& James 2004; Maywald et al., 2004; Melnyk et al., 2000).

Evaluating the impact of MI answers was mostly conducted by asking clinicians about patient outcome using pre-defined outcome categories either via surveys or structured interviews. These were either based on outcomes previously used in clinical pharmacy studies, or seemingly investigator/MI staff devised. Only Hedegaard used interviews with doctors to help inform the content of their survey questions, one of which explored impact of the answer provided (Hedegaard \& Damkier, 2009), whilst Rutter et al explored clinician utilisation of advice through thematic analysis of semi-structured interviews (Rutter et al., 2015). Those studies that sought patient's opinions also used pre-defined outcome categories (Badiani et al., 2017; Bramley et al., 2018; Joseph \& James, 2004; Maywald et al., 2004; Melnyk et al., 2000). For those studies utilising survey methodology, some included open ended questions allowing additional data 
on patient outcomes to be gained. For example, Stubbington et al were able to theme responses about use of $\mathrm{Ml}$ advice to provide greater context, which included to reassure the patient and/or clinician', 'to influence treatment choice', 'facilitate diagnosis' or 'pass information to another clinician' (Stubbington et al., 1998).

Most studies were general in nature with no limits on the type of enquiry included, however three studies restricted the sample to a specific type of enquiry; Stubbington evaluated adverse effect questions (Stubbington et al., 1998), whilst Frost Widnes included only questions about pregnancy (Frost Widnes \& Schjøtt 2009) and Strobach selected drug-drug interaction questions (Strobach et al., 2015). Studies ranged in duration from 2 weeks, (Bramley et al., 2009) to the longest studies being 18 and 24 months respectively (Maywald et al., 2004; Schjøtt et al., 2002). In studies where lag time between generation of enquiry and follow-up was captured this tended to be short, typically two to four weeks (Bramley et al., 2009; Bramley et al., 2013; Melnyk et al., 2000; Strobach et al., 2015).

All papers were reviewed where data relating to descriptions around impact and outcome were mentioned. These were themed under five main headings:

- Theme 1: views of clinicians about the effect of MI advice on patients

- Theme 2: actions of clinicians after receiving $\mathrm{MI}$ advice

- Theme 3: influence on their decision-making

- Theme 4: views of patients about the effect of MI advice

- Theme 5: process measures

\section{Theme 1 - Views of clinicians on the effect of MI advice on patients}

Seven studies attempted to determine clinician opinion about the impact MI advice on patient care (Bertsche et al., 2007; Bramley et al., 2009; Bramley et al., 2013; Cardoni \& Thompson, 1978; Innes et al., 2014; Melnyk et al., 2000; Stubbington et al., 1998), although two studies were primarily user satisfaction surveys with supplementary question(s) about impact/patient outcomes (Bertsche et al., 2007; Frost Widnes \& Schjøtt, 2009).

In one structured (Cardoni \& Thompson, 1978) and two semi-structured telephone interviews (Melnyk et al., 2000; Bramley et al., 2009), clinicians were asked to assess patient outcome against pre-defined patient outcomes. In the Cardoni study, $58 \%$ of clinicians $(n=202)$ thought the information had affected patient outcomes, and had a positive effect on patients and their care $(78 \%, n=157)$ as they started or stopped a drug. In almost a third (29\%) of cases clinicians selected the option "other", but data was lacking to determine what these responses meant (Cardoni \& Thompson, 1978). In the Melnyk study, 98 enquiries generated 230 recommendations by the Ml service (Melnyk et al., 2000). Seventy-two respondents (74\%) believed the advice had a beneficial impact on the patient, with an expert panel agreeing that $36(46.8 \%)$ had resulted in a positive patient outcome; ten of which were based on objective measures, e.g. reduction in blood pressure.

In the small study by Bramley et al in 2009, 40 clinicians were asked three questions before receiving advice, one of which was centred on clinician expected patient outcome (Bramley et al., 2009). Thirty-two clinicians were available for follow-up, of 
which $59 \%(n=19)$ of patient outcomes were as expected, three $(9 \%)$ had improved further than expected, although six (19\%) had not improved compared to what had been anticipated.

Bramley and co-workers have subsequently published other works to try and measure the impact of MI answers (Bramley et al., 2013; Innes et al., 2014). Their study in 2013 was much larger (with 179 sets of complete data derived from 316 initial enquiries) than the 2009 paper (Bramley et al., 2013). The majority of enquirers $(81 \%, n=145)$ rated the impact on patient care or outcome as positive: $20 \%(n=35)$ said it improved patient outcome and $62 \%(n=110)$ replied that their patients' care was improved. Only $15 \%(n=27)$ reported no impact. No negative outcomes or cases of worsened patient care were reported. An expert panel purposively reviewed 20 cases, and found that $19(95 \%)$ of cases had a positive impact on patient care.

Leading on from the 2013 study, Innes et al, using the same methodology, completed a larger $(n=1450)$ UK multi-centre $(n=62)$, study (Innes et al., 2014). Positive findings on the impact on patient care were reported and mirrored the Bramley 2013 study. For example, the majority of respondents self-reported that the advice had a positive impact on their patients $(92 \%, n=597 / 647)$, with $85 \%(n=547)$ considering this was positive regarding patient care or outcome. Furthermore, around half $(53 \%, n=343)$ agreed $\mathrm{Ml}$ advice reduced/decreased risk of an adverse drug reaction (ADR) and positively affected lowering risk/improving safety $(58 \%, n=374)$.

Bertsche et al, also used survey methodology that primarily addressed user satisfaction, although one question in the survey looked at patient outcome (Bertsche et al., 2007). Almost half of the clinicians $(42 \%, n=190)$ agreed there was a potential positive outcome, and thematic analysis of these responses revealed that MI advice allowed a switch to more suitable medicine, correct/optimum dosing, enhanced adherence or avoided an interaction.

Stubbington et al mailed a questionnaire to determine the action taken by clinicians as a result of the information provided (Stubbington et al., 1998). Almost all respondents $(95 \%, n=125)$ said they found the information helped, with the authors concluding that the $\mathrm{Ml}$ service had a favourable impact on patient care in at least 40 patients $(30 \%)$. The patient progress after the Ml advice was known in 79 cases (60\%); this included 40 responses of patient improvement.

\section{Theme 2 - Actions of clinicians after receiving $\mathrm{Ml}$ advice}

Twelve studies attempted to determine how clinicians used the information provided (Bertsche et al., 2007; Bramley et al., 2009; Bramley et al., 2013; Frost Widnes \& Schjøtt, 2009; Hedegaard \& Damkier, 2009; Innes et al., 2014; McEntee et al., 2010; Melnyk et al., 2000; Schjøtt et al., 2002; Stubbington et al., 1998; Rutter et al., 2015; Strobach et al., 2015). Most $(n=8)$ were self-administered surveys, four of which were primarily user satisfaction surveys with supplementary question(s) about impact/patient outcomes (Bertsche et al., 2007; Frost Widnes \& Schjøtt, 2009; Hedegaard \& Damkier, 2009; Schjøtt et al., 2002). All studies report high levels of clinician action subsequent to receiving the information, actions ranged from starting, stopping or changing treatment to use in future patient care, 
Stubbington et al found a high proportion $(89 \%, \mathrm{n}=117)$ of clinicians acted on the $\mathrm{MI}$ advice (Stubbington et al., 1998). These were categorised as: starting new treatments $(n=21)$; stopping treatments $(n=20)$; avoidance of a potential adverse event $(n=21)$ to modify a patient's existing treatment $(n=20)$; to stop an adverse event from getting worse $(n=7)$; and to justify current therapy $(n=16)$.

Melnyk et al, also reported a high number of clinicians acting on $\mathrm{Ml}$ advice $(84 \%$ of $230 \mathrm{MI}$ recommendations were accepted) with the highest reported use $(41 \%, \mathrm{n}=78)$ being for provision of information/education, whilst other actions included referral to another clinician (13\%), instigation of additional monitoring $(10 \%)$ and recommending or adding a drug (13\%) (Melnyk et al., 2000).

Similarly, in the Schjøtt study more than half $(61 \%, n=71)$ of those doctors responding stated that the information provided had caused a change in clinical practice, with 68 going on to describe this change (Schjøtt et al., 2002). These were categorised as changes in pharmacotherapy $(n=32)$, improved advice to patients and colleagues $(n=22)$, stopping a medicine $(n=10)$, avoidance of abortion $(n=2)$, and reporting an adverse drug reaction $(n=2)$. According to Hedegaard (2009) most doctors (93\%) used the $\mathrm{MI}$ answer, with many using the answer for patient information (79\%), to change treatment $(45 \%)$, to disseminate to colleagues (51\%) and for future use with patients $(67 \%)$ (Hedegaard \& Damkier, 2009). Again many respondents $(81 \%, n=430)$ in the McEntee et al study acted on the Ml answer provided (McEntee et al., 2010). They used this information to manage a current patient or to plan care of future patients (29\%), for continuing professional development (CPD) purposes (24\%) and for training/teaching $(16 \%)$.

In the Frost Widnes study looking at pregnancy queries, advice was used in some cases to avoid termination $(9 \%, n=11)$, although frequently it informed them to either avoid/stop a medicine $(29 \%, \mathrm{n}=36)$ or start/continue a medicine $(38 \%, \mathrm{n}=47)$ (Frost Widnes \& Schjøtt, 2009).

In the 2009 Bramley paper, 30 (94\%) clinicians had used the information provided, most frequently to start a medicine $(25 \%, n=8)$, to change administration/dosing $(9 \%$, $\mathrm{n}=3)$ or not to start a medicine $(9 \%, \mathrm{n}=3)$ (Bramley et al., 2009). Further studies involving Bramley used similar categorisation to illustrate actions taken. In their 2013 study, a quarter $(n=44)$ continued the medicine, while others started a medicine or changed the drug regimen $(21 \%, \mathrm{n}=37$ for each), with a quarter taking more than one of the listed actions (24\%, $n=43)$ (Bramley et al., 2013). Half $(54 \%, n=97)$ of the enquirers used advice to check medication safety, $30 \%$ to tell them the best plan of action and $22 \%$ to confirm a change in therapy was needed. Similar findings were noted in a 2014 study, where about half $(48 \%, n=311)$ of respondents stated they used it to check the safety or risks of treatment (Innes et al., 2014).

The two most recent studies included in this review were by Strobach and Rutter respectively. Strobach, detailed a total of 232 clinical actions (Strobach et al., 2015). About half of these actions $(49 \%, n=114)$ were considered to be due to Ml advice, and included starting a medicine $(n=34)$; stopping/not starting a medicine $(n=21)$; modifying drug treatment $(n=15)$; clinical monitoring $(n=22)$; specific patient counselling $(n=14)$ and modifying doses $(n=6)$. In the Rutter study 5 key themes were identified after interviewing 40 clinicians, two of which were 'prescriber action' and 'patient outcome' 
(Rutter et al., 2015). Almost all $(n=38)$ used the advice in patient care, with 21 clinicians directly citing how this had a favourable effect on patient care.

\section{Theme 3: Influence on their decision-making}

Besides Ml advice causing clinicians to take specific actions, some studies also reported how $\mathrm{Ml}$ advice influenced their decision making. In three studies this was framed as a more theoretical question. In the Frost Widnes study (Frost Widnes \& Schjøtt, 2009), when asked if advice was important in their therapeutic decision making, the majority agreed $(95 \%, n=111)$. In the Bramley et al 2013 study, just under half $(44 \%, n=79)$ agreed that the $\mathrm{Ml}$ advice played a part in their decision-making process (Bramley et al., 2013), and this was also reflected in the Innes study (Innes et al., 2014). In the Rutter study, usefulness of MI advice was articulated by clinicians as empowering them to make decisions through increased confidence (Rutter et al., 2015).

Clinicians could also be seen to use $\mathrm{Ml}$ advice as a risk management tool, to allow medication safety checks (Bramley et al., 2013), help with their own risk/benefit assessment (Bertsche et al., 2007; Frost Widnes \& Schjøtt, 2009), or ability to explain risk/benefit to the patient (Innes et al., 2014; Rutter et al., 2015).

\section{Theme 4: Views of patients}

Five studies attempted to determine the views patients had on the outcome of answers to their own enquiries they received from MI Services (Badiani et al., 2017; Bramley et al., 2018; Joseph \& James 2004; Maywald et al., 2004; Melnyk et al., 2000). The study by Melnyk et al also involved clinicians and is reported in theme 2 . It must be noted that Melnyk reported data as 'consumers', and it is not completely clear exactly who was a consumer. The authors reported on 68 consumer enquiries, in which $87 \%$ of recommendations were accepted and $92 \%$ of these were deemed as beneficial to their care (Melnyk et al., 2000). Three other small studies by Joseph, Badiani and Bramley investigated the usefulness of answers provided to patients of a medicines helpline after hospital discharge (Badiani et al., 2017; Bramley et al., 2018; Joseph \& James 2004). Joseph asked patients if they followed the advice given, and about actions they took (Joseph \& James, 2004). Almost all patients who replied $(97 \%, \mathrm{n}=58)$ said they followed the recommendations provided, and overall, two thirds $(66 \%, n=40)$ said a medicine-related problem was avoided; three quarters $(75 \%, n=45)$ also reported being less anxious. Similarly, findings from the study by Badiani, involving 68 patients, revealed almost all (96\%) followed the advice to some degree. Respondents believed advice received had avoided a medicine-related problem (27\%) or the medicine problem had resolved (52\%). Almost half $(45 \%)$ of the respondents stated they felt reassured after gaining the advice. Lastly, Bramley's findings mirror those of Badiani. Of the 67 patient respondents, almost all (93\%), followed the advice provided and felt reassured (81\%) after checking about medicine safety and usage. A small number (19\%) reported improved health or cure following advice received.

Maywald performed a much larger $(n=1686)$ survey study, where patients were asked about how they used MI answers, actions they took and the impact this had (Maywald et al., 2004). Of 920 respondents, over two thirds (68\%) reported increased confidence 
in dealing with prescribed medicines and others said uncertainties about medicines were reduced $(81 \%)$. Over a third $(38 \%)$ used the knowledge provided to discuss the results of $\mathrm{MI}$ advice with their clinician, while some reported a better state of health after implementing $\mathrm{Ml}$ advice $(20 \%)$ and felt advice prevented a visit to their clinician $(18 \%)$.

\section{Theme 5: Process measures}

Three studies used other measures to assess impact of Ml advice (Golightly et al., 1988; Kinky et al., 1999; Marrone \& Heck, 2000). In an early study by Golightly, MI pharmacists assigned pre-defined potential outcomes codes to enquiries they answered from the public (Golightly et al., 1988). The outcome codes included ADR or drug interaction prevented, corrected or explained or therapeutic failure prevented. In the opinion of MI staff, answers given to the public prevented or corrected about three quarters $(76 \%, n=4333)$ of medicine-reported problems.

The other studies considered potential cost savings by using an MI service (Kinky et al., 1999; Marrone \& Heck 2000). In the study by Marrone a simple cost analysis of medicines questions $(n=308)$ was completed by multiplying the time Ml staff spent answering the question by the average salary for types of clinicians asking the question e.g. clinical pharmacist, hospital specialist (Marrone \& Heck 2000). This figure was called practitioner hours saved (PHS). A total of 266 PHS was calculated, which equated to a total annual cost saving of $\$ 43,950$.

Finally, in a study by Kinky (1999), investigators developed a cost avoidance model to determine outcome severity and potential cost savings of the enquiry answering service (Kinky et al., 1999). An expert panel reviewed just over a quarter of all enquiries $(28 \%, n=163)$ by deciding what would have happened if the Ml service had not answered the question by choosing an outcome severity score from a scale of 1 to 6 , where one was categorised as no harm through to six, which was death of the patient secondary to a medicines-related problem. Using this model, potential cost savings were mostly due to prevention of increased monitoring and/or additional treatment $(46 \%, n=77)$, although about half the enquiries had little or no measurable cost impact $(51 \%, n=83)$. Despite this the projected potential minimum annual cost savings were about $\$ 1.7$ million.

\section{Discussion}

This review has attempted to establish what impact pharmacy-led $\mathrm{Ml}$ advice services have on clinician and patient outcomes. Overall, findings from studies asking clinician opinion about the effect MI advice had on patients were positive, with reported high levels of clinician action subsequent to receipt of $\mathrm{Ml}$ advice, for example, many used it to stop or start a medicine or to change treatment. Ml advice did not always result in a direct action but sometimes had other less obvious effects on the clinician; using it in their decision-making, sometimes as a check, or to reassure, confirm or tell them or others what to do. In studies seeking patient opinion about the effects of $\mathrm{Ml}$ advice, they reported feeling more confident and reassured about their medicines, and were able to discuss their treatment with their clinician. Few (and old) studies looked at impact from the perspective of costs saved. Given 
the continuing cost constraints on healthcare services, it is surprising that no recent studies have looked at costs and value for money.

It is encouraging to see studies published after the two 2002 reviews (Hands et al., 2002; Spinewine \& Dean, 2002), especially publications in the last 5 to 10 years, having a greater focus on impact and outcome and adopting more robust and valid ways in assessing these concepts. Recommendations such as the use of rating scales and independent expert clinical panels have been used in some studies and are to be welcomed (Bramley et al., 2013; Bramley et al., 2018; Innes et al., 2014; Joseph \& James 2004).

Despite these positive findings and improved attempts to measure outcome, these findings need to be interpreted with caution due to methodological and study limitations. Firstly, these more recent studies report high levels of unknown patient outcome, which seem to originate from problems associated with follow up times or the enquirer not being in a position to report on patient outcome. All studies, as far as we are aware, used pre-determined, often short follow-up times meaning clinicians often did not know the outcome. Future studies should therefore ideally tailor followup time to each enquiry; this then should allow a higher proportion of clinicians to accurately report patient outcome. Frequently, the enquirer was not the prescriber, with a high proportion of pharmacists generating enquiries. This was recognised by Melnyk, whose study methodology stated that if the enquiry was a pharmacist, then the doctor should be contacted to find out what happened (Melnyk et al., 2000). More recent studies may however be less prone to non-prescriber outcome uncertainty as the role of the pharmacist has become more patient-facing and embedded within clinical teams, and thus involved in decision-making on patient care. Notwithstanding this, it is still the prescriber who is ultimately accountable for prescribing decisions and therefore best placed to describe patient outcome. It is also likely, at times, that the originator of the enquiry may no longer be caring for the patient (e.g. hospital patient discharged into the community); in which case seeking the views of patients is an alternative, but as yet relatively under utilised approach. Additionally, they can also provide insight based on patient perception of outcome rather than those of the clinician. Triangulation studies using patient and clinician views on outcome is another, as yet untested way, of assessing outcome.

Studies have taken a real-world pragmatic approach when trying to establish patient outcome, with a variety of measures used to report on patient outcome. This is understandable given it is almost impossible to use empirical measures to quantify the impact of MI advice. Only Melnyk et al., reported some of their findings based on objective clinical data; reduction of blood pressure as a result of $\mathrm{Ml}$ advice to change an antihypertensive medicine (Melnyk et al., 2000). Studies used clinician opinion, via completion of researcher pre-defined outcome categories, as well as through clinician expectation of anticipated patient response or inference that a reported action may have had a (positive) effect. Use of such measures limits the usefulness of study findings on $\mathrm{Ml}$ advice influencing patient outcome because respondents were not given free choice in explaining outcome or were restricted to theorising outcome. As stated previously, rating scales and expert panels have been used in recent research in an attempt to provide more robust data on the effect of Ml advice. However, the way in which these tools have been developed and used needs to be considered. Work by 
Bramley and co-authors has used rating scales with descriptors of impact (Bramley et al., 2013; Innes et al., 2014). These works appear to use unvalidated scales that over represent the choices toward a positive response, thus introducing potential bias. We acknowledge and appreciate that while Ml advice is unlikely to increase harm, we do not know this for certain, and if reported, what level of harm this may have caused. A recent 2018 study by Bramley et al reported validation of a modified version of their impact rating scale, however the level of detail reported on its validation within the paper makes it difficult to independently assess the authors' conclusions (Bramley et al 2018). The use of expert panels can provide an objective view of patient outcome, with more recent $\mathrm{MI}$ studies utilising this methodology, although only a small proportion of enquiries generated were included and MI pharmacists rarely included as panel members (Bramley et al., 2013; Bramley et al., 2018; Innes et al., 2014; Joseph \& Joseph 2014). The exclusion of MI pharmacists in panels we believe is regrettable as they should be better informed to explain the rationale for MI advice given.

Despite the limitations seen in current MI service research it is recognised that a greater level of understanding on the impact MI services have on patient outcome is now known compared to when the last reviews were conducted. An ability to show impact on patient outcome for MI services is important given they are under increased pressure (Gabay, 2017; NHS England, 2014). Interestingly, and analogous to MI services, the impact of various Health Library Information Services (LIS) has been studied, highlighting limited evidence of impact because of poor study quality (Brettle et al., 2011; Brettle, Maden and Payne, 2016; Marshall, et al., 2013; Perrier et al., 2014; Weightman et al., 2009). As a result of these works and recent questioning about service need, clinical librarians have developed tools to help measure their value and impact (Knowledge for Healthcare Impact and Value Task and Finish Group 2016).

This site suggests conducting face-to-face or telephone interviews to gain a deeper understanding of their service or to supplement data obtained via surveys with interviews as they will provide the explanation of "how" and "why". This approach has been rarely employed by MI studies to date (Rutter et al., 2015).

\section{Conclusion}

$\mathrm{MI}$ advice does contribute to patient outcome although determining to what extent is difficult due to limitations in study design and data capture. The MI service should learn lessons from Health LIS to better evaluate impact and value of the service. Future collaborative work between the two services should be conducted as both service goals are the same, and they provide similar services to clinicians.

\section{References}


Badiani, A., Wills, S., Owen, S., Parker, J. \& Hall, J. (2017). Impact of a medicines helpine for patients. European Journal of Hospital Pharmacy, 24, 196-199. doi:10.1136/ejhpharm-2015-000849.

Bernard, E., Arnould, M., Saint-Lary, O., Duhot, D. \& Hebbrecht, G. (2012). Internet use for information seeking in clinical practice: a cross-sectional survey among French general practitioners. International Journal of Medical Informatics, 81 (7), 493-499. doi.org/10.1016/j.jjmedinf.2012.02.001.

Bertsche, T., Hammerlein, A. \& Schulz, M. (2007). German national drug information service: user satisfaction and potential positive patient outcomes. Pharmacy World and Science, 29 (3), 167-172. doi:10.1007/s11096-006-9041-7.

Bourne, J. (2007). Prescribing costs in primary care. London: National Audit Office.

Bramley, D., Mohandas, C., Soor, S., Erskine, D. \& Oborne, C.A. (2009). Does a medicines information service have a positive impact on patient care? Pharmaceutical Journal, 282, 139-140.

Bramley, D., Innes, A., Duggan, C. \& Oborne, A. (2013). The impact of Medicines Information enquiry answering on patient care and outcomes. International Journal of Pharmacy Practice, 21 (6), 393-404. doi:10.1111/ijpp.12018.

Bramley D., Innes, A. \& Dass, N. (2018) Impact of medicines helplines on patient satisfaction, patient outcomes and medicines safety for hospital patients: the development of a rating scale and an evaluation of patients' opinions. European Journal of Hospital Pharmacy, 24, 196-199. doi:10.1136/ejhpharm-2017-001459.

Brettle, A., Maden, M. and Payne, C. (2016). The impact of clinical librarian services on patients and health care organisations. Health Information \& Libraries Journal, 33 (2), 100-120.

Brettle, A., Maden-Jenkins, M., Anderson, L., McNally, R., Pratchett, T., Tancock, J., Thornton, D. and Webb, A. (2011). Evaluating clinical librarian services: a systematic review. Health Information \& Libraries Journal, 28 (1), 3-22.

Cardoni, A.A. \& Thompson, T.J. (1978). Impact of drug information services on patient care. American Journal of Hospital Pharmacy, 35, 1233-1237.

Clarke, M.A., Belden, J.L., Koopman, R.J., Steege, L.M., Moore, J.L., Canfield, S.M. \& Kim, M.S. (2013). Information needs and information-seeking behaviour analysis of primary care physicians and nurses: a literature review. Health Information and Libraries Journal, 30 (3), 178-190. doi.org/10.1111/hir.12036.

Damarell, R.A. \& Tieman, J.T. (2015). Searching PubMed for a broad subject area: how effective are palliative care clinicians in finding the evidence in their field? Health Information and Libraries Journal, 33, 49-60. doi:10.1111/hir.12120.

Davidoff F., Haynes B., Sackett D. \& Smith, R. (1995). Evidence based medicine. British Medical Journal, 310, 1085-1086. 
European Medicines Agency (2017). Annual activity report 2016. [online] London: European Medicines Agency. Available from: http://www.ema.europa.eu/docs/en GB/document library/Report/2017/07/WC50023 0378.pdf [last accessed 18 August 2018].

Fathelrahman, A.I., Awang, R., Bashir, A.A., Taha, I.A. \& Ibrahim, H.M. (2008). User satisfaction with services provided by a drug information center in Sudan. Pharmacy World and Science, 30 (6), 759-763. doi:10.1007/s11096-008-9245-0.

Frost Widnes, S.F. \& Schjøtt, J. (2009). Drug use in pregnancy-physicians' evaluation of quality and clinical impact of drug information centres. European Journal of Clinical Pharmacology, 65 (3), 303-308. doi:10.1007/s00228-008-0593-4.

Gabay, M.P. (2017). The Evolution of Drug Information Centers and Specialists. Hospital pharmacy, 52 (7), 452-453. doi: 10.1177/0018578717724235.

Golightly, L.K., Davis, A.G., Budwitz, W.J., Gelman, C.J., Rathmann, K.L., Sutherland, E.W. \& Rumack, B.H. (1988). Documenting the activity and effectiveness of a regional drug information center. American Journal of Hospital Pharmacy, 45 (2), 356-61.

Hands, D., Stephens, M., \& Brown, D. (2002). A systematic review of the clinical and economic impact of drug information services on patient outcome. Pharmacy World and Science, 24 (4), 132-138.

Hedegaard, U. \& Damkier, P. (2009). Problem-oriented drug information: physicians' expectations and impact on clinical practice. European Journal of Clinical Pharmacology, 65 (5), 515-522. doi:10.1007/s00228-008-0604-5.

Innes, A., Bramley, D. \& Wills, S. (2014). The impact of UK Medicines Information service on patient care, clinical outcomes and medicines safety: an evaluation of healthcare professionals' opinions. European Journal of Hospital Pharmacy, 21, 222228.

lqbal, A. \& Glenny, A-M. (2002). General dental practitioners' knowledge of and attitudes towards evidence-based practice. British Dental Journal, 193 (10), 587-591. DOI: $10.1038 /$ sj.bdj.4801634.

Joseph, A., Franklin, B.D. \& James, D. (2004). An evaluation of a hospital-based patient medicines information helpline. Pharmaceutical Journal, 272, 126-129.

Kinky, D.E., Erush, S.C., Laskin, M. \& Gibson, G.A. (1999). Economic impact of a drug information service. Annals of Pharmacotherapy, 33, 11-16.

Knowledge for Healthcare Impact and Value Task and Finish Group. Value and impact toolkit for knowledge and library services. [online] England: NHS Library and Knowledge Services. Available from: http://kfh.libraryservices.nhs.uk/value-andimpact-toolkit [Last accessed 17 February 2019]. 
Marrone, C.M. \& Heck, A.M. (2000). Impact of a Drug Information Service: Practitioner Hours Saved. Hospital Pharmacy, 35, 1065-1070.

Marshall, J.G., Sollenberger, J., Easterby-Gannett, S., Morgan, L.K., Klem, M.L., Cavanaugh, S.K., Oliver, K.B., Thompson, C.A., Romanosky, N. and Hunter, S. (2013). The value of library and information services in patient care: results of a multisite study. Journal of the Medical Library Association, 101 (1), 38-46.

Maywald, U., Schindler, C., Krappweis, J. \& Kirch, W. (2004). First Patient-Centered Drug Information Service in Germany-A Descriptive Study. Annals of Pharmacotherapy, 38 (12), 2154-9. doi: 10.1345/aph.1E210.

Melnyk, P.S., Shevchuk, Y.V. \& Remillard, A.J. (2000). Impact of the DIAL Access drug information service on patient outcome. Annals of Pharmacotherapy, 34 (5), 585592. doi:10.1345/aph.19173.

McEntee, J., Henderson, S.L., Rutter, P.M., Rutter, J. \& Davis, H.J. (2010). Utility and value of a medicines information service provided by pharmacists: a survey of health professionals. International Journal of Pharmacy Practice, 18 (6), 353-361. doi: 10.1111/j.2042-7174.2010.00068.x.

NHS England (2014). The Review of Specialist Pharmacy Services in England. [online] London: NHS England. Available from:

https://www.england.nhs.uk/wp-content/uploads/2014/05/sps-final-rep-28-05-14.pdf [last accessed 23 May 2018].

Perrier, L., Farrell, A., Ayala, A.P., Lightfoot, D., Kenny, T., Aaronson, E., Allee, N., Brigham, T., Connor, E., Constantinescu, T., Muellenbach, J., Epstein, H.A. and Weiss, A. (2014). Effects of librarian-provided services in healthcare settings: a systematic review. Journal of the American Medical Informatics Association, 21(6), 1118-1124.

Prescribing and Medicines Team (2017). Prescriptions Dispensed in the Community, England 2006-2016. [online] Leeds: Health and Social Care Information Centre. Available from: http://digital.nhs.uk/catalogue/PUB30014 [last accessed 18 August 2018].

Repchinsky, C.A. \& Masuhara, E.J. (1987). Quality Assurance Program for a Drug Information Center. Annals of Pharmacotherapy, 21 (10), 816-820.

Rutter, J., Morgan, R., Fitzpatrick, R. \& Rutter P. (2015). The provision of medicines advice to primary care prescribers: Effect on decision-making and patient care. Journal of Evaluation Clinical Practice, 21, 307-312. doi: 10.1111/jep.12310

Schjøtt, J., Pomp, E. \& Gedda-Dahl, A. (2002). Quality and impact of problem-oriented drug information: a method to change clinical practice among physicians? European Journal of Clinical Pharmacology, 57 (12), 897-902. 
Spinewine, A. \& Dean, B. (2002). Measuring the impact of medicines information services on patient care: methodological considerations. Pharmacy World and Science, 24 (5), 177-181.

Strobach, D., Gruber, A.C., Möhler, N.C. \& Vetter-Kerkhoff, C. (2015). Clinical impact of the hospital pharmacy drug information service: how does information on drug-drug interaction enquiries translate into clinical decisions? European Journal of Hospital Pharmacy, 22, 83-88.

Stubbington, C., Bowey, J., Hands, D. \& Brown, D. (1998). Drug information on replies to queries involving adverse events: impact on clinical practice. Hospital Pharmacist, $5,81-84$.

Weightman, A., Urquhart, C., Spink, S., Thomas, R. and National Library for Health Library Services Development Group. (2009). The value and impact of information provided through library services for patient care: developing guidance for best practice. Health information \& Libraries journal, 26 (1), 63-71.

Zwolsman, S. (2012). Barriers to GPs' use of evidence-based medicine: a systematic review. British Journal of General Practice, 62, e511-21.doi. org/10.3399/bjgp12X652382.

Figures and Tables

Figure 1: Selection Process of Papers for Review

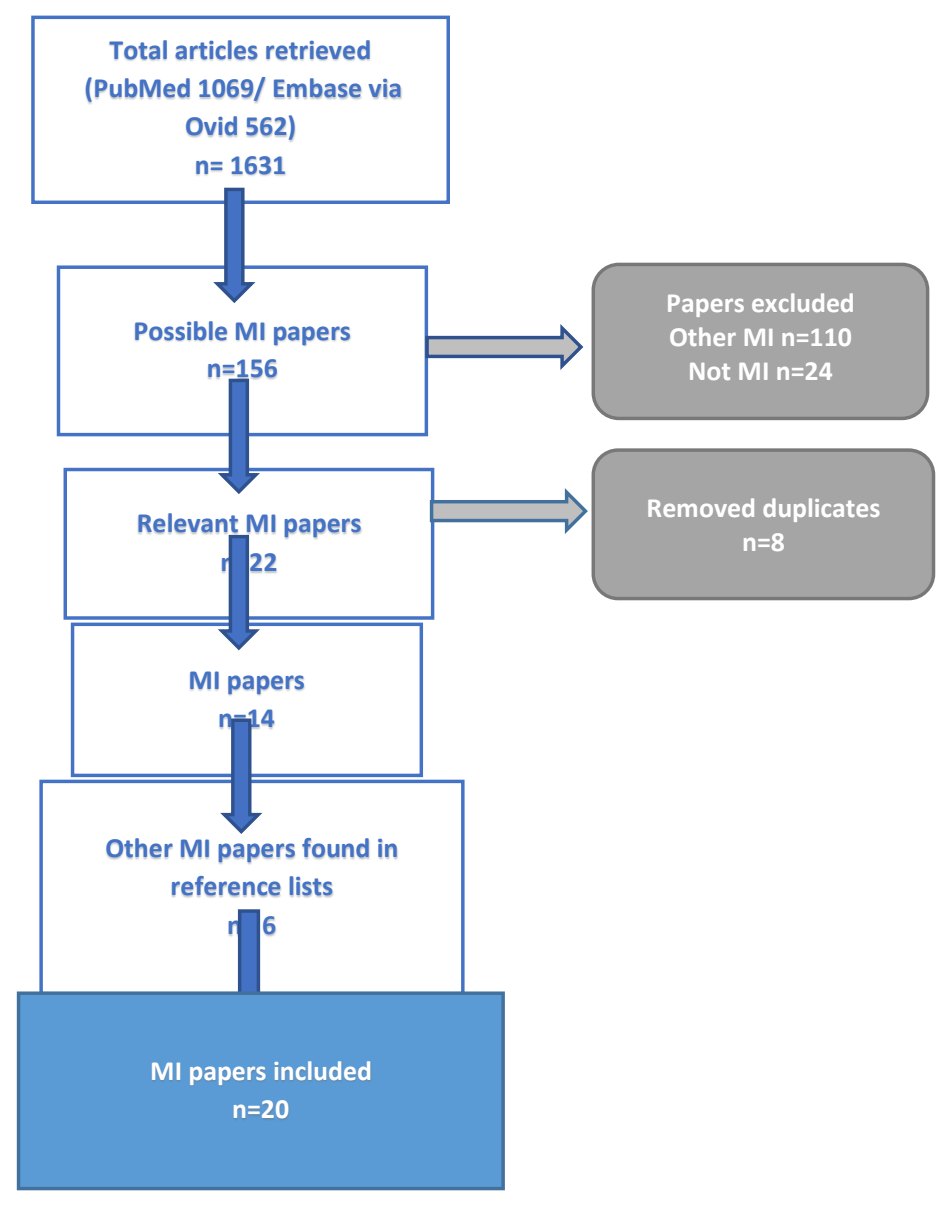


Table 1 Search Strategy and results

\begin{tabular}{|c|c|c|c|c|}
\hline Database & \multicolumn{3}{|c|}{ Search terms used } & Number of hits \\
\hline $\begin{array}{l}\text { Medline } \\
\text { (Pubmed) } \\
\text { [MeSH Terms*] }\end{array}$ & \multicolumn{4}{|c|}{$\begin{array}{l}\text { From } 1966 \text { to Feb } 2019 \\
\text { Limited to human \& English Language } \\
\text { Terms in "quotes" were free text }\end{array}$} \\
\hline Search 1 & $\begin{array}{l}\text { drug } \\
\text { information } \\
\text { services* } \\
\text { (exp) } \\
\text { AND }\end{array}$ & $\begin{array}{l}\text { clinical } \\
\text { pharmacy } \\
\text { services* } \\
\text { (exp) } \\
\text { OR }\end{array}$ & $\begin{array}{l}\text { community } \\
\text { pharmacy } \\
\text { services* } \\
(\exp )\end{array}$ & 524 \\
\hline Search 2 & $\begin{array}{l}\text { "drug } \\
\text { information" } \\
\text { OR }\end{array}$ & $\begin{array}{l}\text { "medicines } \\
\text { information" } \\
\text { AND }\end{array}$ & "service" & 708 \\
\hline $\begin{array}{l}\text { Search } 1 \\
\text { AND } \\
\text { Search } 2\end{array}$ & 1069 hits & & & $\begin{array}{l}6 \text { selected } \\
19 \text { not Ml } \\
68 \text { MI but not } \\
\text { relevant } \\
9 \text { relevant MI } \\
\text { studies } \\
\text { (Cardoni } 1978 \\
\text { Kinky } 1999 \\
\text { Melnyk } 2000 \\
\text { Maywald } 2004 \\
\text { Bertsche } 2007 \\
\text { Frost Widnes } 2009 \\
\text { Hedegaard 2009 } \\
\text { Bramley 2013 } \\
\text { Rutter 2015) }\end{array}$ \\
\hline $\begin{array}{l}\text { Embase } \\
\text { (via Ovid) } \\
\text { [EmTree terms*] }\end{array}$ & \multicolumn{4}{|c|}{$\begin{array}{l}\text { From } 1974 \text { to Feb } 2019 \\
* * \text { Limited to human \& English Language } \\
\text { Terms in "quotes" were free text }\end{array}$} \\
\hline Search 1 & $\begin{array}{l}\text { drug } \\
\text { information* } \\
\text { (exp) } \\
\text { AND }\end{array}$ & $\begin{array}{l}\text { information } \\
\text { service* } \\
\text { (exp) }\end{array}$ & $\begin{array}{c}616\left(\text { limit }^{\star *}\right) \\
=182\end{array}$ & $\begin{array}{l}25 \text { selected } \\
3 \text { not Ml } \\
19 \text { MI but not } \\
\text { relevant } \\
3 \text { relevant MI } \\
\text { studies (1 new) } \\
\text { (Cardoni } 1978 \\
\text { Melnyk } 2000 \\
\text { Strobach } 2015 \text { ) }\end{array}$ \\
\hline Search 2 & $\begin{array}{l}\text { drug } \\
\text { information* } \\
\text { (focussed) } \\
\text { OR } \\
\text { "medicines } \\
\text { information" }\end{array}$ & $\begin{array}{c}\text { AND } \\
\text { "impact" } \\
\text { OR } \\
\text { "outcome" } \\
\text { OR } \\
\text { patient care* } \\
\text { (focussed) }\end{array}$ & $\begin{array}{l}554\left(\operatorname{limit}^{* *}\right) \\
=380\end{array}$ & $\begin{array}{l}35 \text { selected } \\
2 \text { not Ml } \\
23 \text { Ml but not } \\
\text { relevant } \\
10 \text { relevant Ml } \\
\text { studies (4 new) } \\
\text { (Melnyk } 2000 \\
\text { Joseph } 2004 \\
\text { Maywald } 2004 \\
\text { Frost Widnes } 2009 \\
\text { Bramley } 2009 \\
\text { Bramley } 2013 \\
\text { Innes } 2014 \\
\text { Rutter } 2015 \\
\text { Strobach } 2015 \\
\text { Bramley 2018) }\end{array}$ \\
\hline
\end{tabular}


Table 2: Summary of Papers

\begin{tabular}{|c|c|c|c|c|c|c|c|c|c|}
\hline $\begin{array}{l}\text { Study } \\
\text { author } \\
\text { (Year) }\end{array}$ & Country & $\begin{array}{c}\text { Aim \& } \\
\text { objectives }\end{array}$ & $\begin{array}{l}\text { Study } \\
\text { participants }\end{array}$ & $\begin{array}{l}\text { Study } \\
\text { design }\end{array}$ & Duration & Sampling & Method & $\begin{array}{l}\text { Number of } \\
\text { participants } \\
\text { /enquiries } \\
\text { Response rate } \\
\text { where } \\
\text { appropriate }\end{array}$ & Outcome measure(s) \\
\hline $\begin{array}{c}\text { Cardoni } \\
\text { et al } \\
(1978)\end{array}$ & US & $\begin{array}{l}\text { To investigate the } \\
\text { use of MI } \\
\text { answers and the } \\
\text { effect on patient } \\
\text { care }\end{array}$ & $\begin{array}{l}\text { Clinicians } \\
\text { from primary } \\
\text { and } \\
\text { secondary } \\
\text { care, } \\
\text { although this } \\
\text { was unclear }\end{array}$ & $\begin{array}{l}\text { Retrospective } \\
\text { Single site }\end{array}$ & 14 weeks & $\begin{array}{l}\text { Patient- } \\
\text { specific } \\
\text { enquiries }\end{array}$ & Telephone survey & $\begin{array}{l}491 \text { enquiries } \\
430 \text { responses } \\
(90 \%)\end{array}$ & $\begin{array}{l}\text { Specific outcome(s) of Medicines related } \\
\text { problems } \\
\text { Effect on patient outcome }\end{array}$ \\
\hline $\begin{array}{c}\text { Golightly } \\
\text { et al } \\
(1988)\end{array}$ & US & $\begin{array}{l}\text { To document the } \\
\text { activity and } \\
\text { effectiveness of an } \\
\text { MI service }\end{array}$ & $\begin{array}{l}\text { Clinicians and } \\
\text { public in } \\
\text { primary and } \\
\text { secondary } \\
\text { care }\end{array}$ & $\begin{array}{l}\text { Retrospective } \\
\text { Single site }\end{array}$ & 12 months & $\begin{array}{l}\text { All enquiries } \\
\text { received }\end{array}$ & $\begin{array}{l}\text { In-house review } \\
\text { Enquiries were } \\
\text { coded by MI staff } \\
\text { with potential } \\
\text { outcome }\end{array}$ & $\begin{array}{l}11424 \text { clinician } \\
\text { enquiries } \\
16657 \text { public } \\
\text { enquiries } \\
34 \% \text { ( } n=5702 \text { ) } \\
\text { public enquires } \\
\text { related to MRP } \\
\text { were coded }\end{array}$ & $\begin{array}{l}\text { Potential outcome codes for public } \\
\text { enquiries: } \\
\text { ADR prevented/corrected/explained } \\
\text { Compliance improved/reinforced } \\
\text { Drug interaction prevented/corrected/ } \\
\text { explained } \\
\text { Therapeutic failure prevented } \\
\text { Medical problem referred } \\
\text { drug misuse prevented/corrected }\end{array}$ \\
\hline $\begin{array}{c}\text { Kinky et al } \\
(1999)\end{array}$ & US & $\begin{array}{l}\text { To develop a cost } \\
\text { avoidance model } \\
\text { to determine } \\
\text { potential cost } \\
\text { savings of an MI } \\
\text { enquiry answering } \\
\text { service }\end{array}$ & $\begin{array}{l}\text { Clinicians in } \\
\text { secondary } \\
\text { care }\end{array}$ & $\begin{array}{l}\text { Prospective } \\
\text { Single site }\end{array}$ & 6 weeks & \begin{tabular}{|l} 
Patient- \\
specific \\
enquiries
\end{tabular} & $\begin{array}{l}\text { Cost avoidance } \\
\text { model developed } \\
\\
\text { Outcome/severity } \\
\text { level assigned by } \\
\text { expert panel }\end{array}$ & $\begin{array}{l}163 / 570 \\
\text { enquiries } \\
\text { (29\% reviewed) }\end{array}$ & $\begin{array}{l}\text { Optimal results } \\
\text { Treatment failure } \\
\text { New medical problem } \\
\text { Treatment failure and new medical problem } \\
\text { Costs avoided }\end{array}$ \\
\hline $\begin{array}{c}\text { Stubbington } \\
\text { et al } \\
(1998)\end{array}$ & UK & $\begin{array}{l}\text { To find out how } \\
\text { MI replies to } \\
\text { enquiries about } \\
\text { adverse effects } \\
\text { (AE) influenced } \\
\text { clinical practice }\end{array}$ & $\begin{array}{l}\text { Clinicians in } \\
\text { primary and } \\
\text { secondary } \\
\text { care }\end{array}$ & $\begin{array}{l}\text { Retrospective } \\
\text { Single site }\end{array}$ & 12 weeks & $\begin{array}{l}\text { Patient- } \\
\text { specific } \\
\text { adverse effect } \\
\text { enquiries }\end{array}$ & $\begin{array}{l}\text { Postal } \\
\text { questionnaire }\end{array}$ & $\begin{array}{l}132 / 161 \\
\text { (82\% response } \\
\text { rate) }\end{array}$ & $\begin{array}{l}\text { Action taken as result of MI answer } \\
\text { Effect on subsequent patient progress } \\
\text { Effect on CPD }\end{array}$ \\
\hline
\end{tabular}




\begin{tabular}{|c|c|c|c|c|c|c|c|c|c|}
\hline $\begin{array}{l}\text { Study } \\
\text { author } \\
\text { (Year) }\end{array}$ & Country & $\begin{array}{c}\text { Aim \& } \\
\text { objectives }\end{array}$ & $\begin{array}{l}\text { Study } \\
\text { participants }\end{array}$ & $\begin{array}{l}\text { Study } \\
\text { design }\end{array}$ & Duration & Sampling & Method & $\begin{array}{l}\text { Number of } \\
\text { participants } \\
\text { /enquiries } \\
\text { Response rate } \\
\text { where } \\
\text { appropriate }\end{array}$ & Outcome measure(s) \\
\hline $\begin{array}{c}\text { Marrone et } \\
\text { al } \\
(2000)\end{array}$ & US & $\begin{array}{l}\text { To determine the } \\
\text { economic impact } \\
\text { of the MI service } \\
\text { by measuring } \\
\text { practitioner hours } \\
\text { saved and } \\
\text { associated costs }\end{array}$ & $\begin{array}{l}\text { Clinicians in } \\
\text { secondary } \\
\text { care }\end{array}$ & $\begin{array}{l}\text { Prospective } \\
\text { Single site }\end{array}$ & 12 weeks & All enquiries & $\begin{array}{l}\text { Cost analysis } \\
\text { Practitioner Hours } \\
\text { Saved (PHS) } \\
\text { calculated by } \\
\text { multiplying time } \\
\text { to find answer } \\
\text { and give a } \\
\text { response by } \\
\text { average salary for } \\
\text { each clinician type }\end{array}$ & $\begin{array}{l}308 / 347 \\
\text { enquiries } \\
\text { ( } 89 \% \text { of } \\
\text { enquiries) }\end{array}$ & $\begin{array}{l}\text { PHS by use of the MI enquiry service } \\
\text { Potential costs saved by using the MI } \\
\text { enquiry service }\end{array}$ \\
\hline $\begin{array}{c}\text { Melnyk et } \\
\text { al } \\
(2000)\end{array}$ & Canada & $\begin{array}{l}\text { To determine the } \\
\text { impact of the MI } \\
\text { answers on } \\
\text { patient outcomes }\end{array}$ & $\begin{array}{l}\text { Public and } \\
\text { clinicians in } \\
\text { primary and } \\
\text { secondary } \\
\text { care }\end{array}$ & $\begin{array}{l}\text { Prospective } \\
\text { Single site }\end{array}$ & 14 weeks & $\begin{array}{l}\text { Patient- } \\
\text { specific } \\
\text { enquiries }\end{array}$ & $\begin{array}{l}\text { Semi-structured } \\
\text { telephone } \\
\text { interviews } \\
\text { Initial follow-up } \\
\text { after } 1 \text {-2 days, } \\
\text { then up to } 6 \\
\text { weeks after MI } \\
\text { answer was } \\
\text { provided }\end{array}$ & $\begin{array}{l}64 / 68 \text { public } \\
\text { (94\% response } \\
\text { rate) } \\
98 / 98 \text { clinicians } \\
\text { (100\% response } \\
\text { rate) }\end{array}$ & $\begin{array}{l}\text { Desired outcome } \\
\text { Actual patient outcome } \\
\text { Enquirer opinion of impact on patient } \\
\text { outcome } \\
\text { Views of a clinical panel on impact on } \\
\text { patient outcome }\end{array}$ \\
\hline $\begin{array}{c}\text { Schjott } \\
\text { al } \\
(2002)\end{array}$ & Norway & $\begin{array}{l}\text { To determine the } \\
\text { impact of MI } \\
\text { answers on } \\
\text { clinicians }\end{array}$ & $\begin{array}{l}\text { Doctors in } \\
\text { primary and } \\
\text { secondary } \\
\text { care }\end{array}$ & $\begin{array}{l}\text { Retrospective } \\
\text { Single site }\end{array}$ & $\begin{array}{l}18 \\
\text { months }\end{array}$ & $\begin{array}{l}\text { All enquiries } \\
\text { answered in } \\
\text { writing } \\
\text { Excluded } \\
\text { simple } \\
\text { questions } \\
\text { answered by } \\
\text { telephone }\end{array}$ & $\begin{array}{l}\text { Postal } \\
\text { questionnaire }\end{array}$ & $\begin{array}{l}117 / 163 \\
\text { doctors } \\
\text { (72\% response } \\
\text { rate) }\end{array}$ & $\begin{array}{l}\text { Change in clinical practice } \\
\text { Use of MI answer with patients }\end{array}$ \\
\hline $\begin{array}{l}\text { Maywald } \\
\text { et al } \\
(2004)\end{array}$ & Germany & $\begin{array}{l}\text { To find out the } \\
\text { outcome of MI } \\
\text { answers provided } \\
\text { to patients }\end{array}$ & $\begin{array}{l}\text { Patients in } \\
\text { primary care }\end{array}$ & $\begin{array}{l}\text { Prospective } \\
\text { Single site }\end{array}$ & 24 months & $\begin{array}{l}\text { Patient- } \\
\text { specific } \\
\text { enquiries } \\
\text { received and } \\
\text { answered by } \\
\text { telephone }\end{array}$ & $\begin{array}{l}\text { Postal } \\
\text { questionnaire }\end{array}$ & $\begin{array}{l}920 / 1686 \\
\text { (58\% response } \\
\text { rate) }\end{array}$ & $\begin{array}{l}\text { Use of MI answer } \\
\text { Action taken } \\
\text { Impact on the patient }\end{array}$ \\
\hline
\end{tabular}




\begin{tabular}{|c|c|c|c|c|c|c|c|c|c|}
\hline $\begin{array}{l}\text { Study } \\
\text { author } \\
\text { (Year) }\end{array}$ & Country & $\begin{array}{c}\text { Aim \& } \\
\text { objectives }\end{array}$ & $\begin{array}{l}\text { Study } \\
\text { participants }\end{array}$ & $\begin{array}{l}\text { Study } \\
\text { design }\end{array}$ & Duration & Sampling & Method & $\begin{array}{l}\text { Number of } \\
\text { participants } \\
\text { /enquiries } \\
\text { Response rate } \\
\text { where } \\
\text { appropriate }\end{array}$ & Outcome measure(s) \\
\hline $\begin{array}{c}\text { Joseph } \\
\text { et al } \\
(2004)\end{array}$ & UK & $\begin{array}{l}\text { To determine } \\
\text { impact of a MI } \\
\text { patient helpline } \\
\text { on patient } \\
\text { outcomes }\end{array}$ & $\begin{array}{l}\text { Patients } \\
\text { discharged } \\
\text { from the } \\
\text { hospital or } \\
\text { seen as } \\
\text { outpatients }\end{array}$ & $\begin{array}{l}\text { Prospective } \\
\text { Single site }\end{array}$ & 8 weeks & $\begin{array}{l}\text { Patient- } \\
\text { specific } \\
\text { enquiries }\end{array}$ & $\begin{array}{l}\text { Postal } \\
\text { questionnaire } \\
\text { Expert panel } \\
\text { assessed MI } \\
\text { recommendations }\end{array}$ & $\begin{array}{l}58 / 87 \\
\text { (67\% response } \\
\text { rate }\end{array}$ & $\begin{array}{l}\text { Advice followed } \\
\text { Action taken } \\
\text { Impact on wellbeing }\end{array}$ \\
\hline $\begin{array}{c}\text { Bertsche } \\
\text { et al } \\
(2007)\end{array}$ & Germany & $\begin{array}{l}\text { To explore the } \\
\text { impact of the MIS } \\
\text { on patient } \\
\text { outcomes based } \\
\text { on clinician } \\
\text { judgement }\end{array}$ & $\begin{array}{l}\text { Clinicians in } \\
\text { primary care }\end{array}$ & $\begin{array}{l}\text { Prospective } \\
\text { Single site }\end{array}$ & $\begin{array}{l}12 \\
\text { months }\end{array}$ & $\begin{array}{l}\text { Patient- } \\
\text { specific } \\
\text { enquiries }\end{array}$ & $\begin{array}{l}\text { Faxed } \\
\text { questionnaire }\end{array}$ & $\begin{array}{l}455 / 1017 \\
\text { clinicians } \\
\text { (45\% response } \\
\text { rate) }\end{array}$ & Potential positive patient outcomes \\
\hline $\begin{array}{c}\text { Frost } \\
\text { Widnes } \\
\text { et al } \\
(2009)\end{array}$ & Norway & $\begin{array}{l}\text { To assess the } \\
\text { clinical impact of } \\
\text { MI answers } \\
\text { provided about } \\
\text { medicines in } \\
\text { pregnancy } \\
\text { question } \\
\end{array}$ & $\begin{array}{l}\text { Doctors in } \\
\text { primary and } \\
\text { secondary } \\
\text { care }\end{array}$ & $\begin{array}{l}\text { Prospective } \\
\text { Muticentre } \\
(n=5)\end{array}$ & $\begin{array}{l}12 \\
\text { months }\end{array}$ & $\begin{array}{l}\text { Patient- } \\
\text { specific } \\
\text { pregnancy } \\
\text { enquiries }\end{array}$ & $\begin{array}{l}\text { Postal/email } \\
\text { questionnaire }\end{array}$ & $\begin{array}{l}123 / 162 \\
\text { (76\% response } \\
\text { rate }\end{array}$ & $\begin{array}{l}\text { Importance of answer on therapeutic } \\
\text { decision } \\
\text { Use in decision making: } \\
\text { Asked if agreed with the statement: } \\
\text { "the answer from the [MIS] was important } \\
\text { for my therapeutic decision" }\end{array}$ \\
\hline $\begin{array}{c}\text { Hedegaard } \\
\text { et al } \\
(2009)\end{array}$ & Denmark & $\begin{array}{l}\text { To evaluate the } \\
\text { clinical impact of } \\
\text { MI answers }\end{array}$ & $\begin{array}{l}\text { Doctors in } \\
\text { primary and } \\
\text { secondary } \\
\text { care }\end{array}$ & $\begin{array}{l}\text { Prospective } \\
\text { Single site }\end{array}$ & $\begin{array}{l}12 \\
\text { months }\end{array}$ & $\begin{array}{l}\text { Patient- } \\
\text { specific } \\
\text { enquiries } \\
\text { answered in } \\
\text { writing }\end{array}$ & $\begin{array}{l}\text { Initial interviews } \\
\text { to inform content } \\
\text { of postal } \\
\text { questionnaire }\end{array}$ & $\begin{array}{l}183 / 197 \\
\text { (93\% response } \\
\text { rate) }\end{array}$ & How MI answer was used \\
\hline $\begin{array}{c}\text { Bramley } \\
\text { et al } \\
(2009)\end{array}$ & UK & $\begin{array}{l}\text { To find out: } \\
\text { Proportion of } \\
\text { enquiries where } \\
\text { MI advice was } \\
\text { used in patient } \\
\text { care } \\
\text { What clinicians } \\
\text { did with }\end{array}$ & $\begin{array}{l}40 \text { clinicians } \\
\text { Presumably } \\
\text { mostly from } \\
\text { secondary } \\
\text { care, } \\
\text { although this } \\
\text { was not } \\
\text { specified }\end{array}$ & $\begin{array}{l}\text { Prospective } \\
\text { Multicentre } \\
(n=2)\end{array}$ & 2 weeks & $\begin{array}{l}\text { Patient- } \\
\text { specific } \\
\text { enquiries }\end{array}$ & $\begin{array}{l}\text { Semi-structured } \\
\text { telephone } \\
\text { interviews at } 7 \text { to } \\
28 \text { days post } \\
\text { enquiry being } \\
\text { generated }\end{array}$ & 32 interviewed & $\begin{array}{l}\text { Number of enquiries used answer/followed } \\
\text { advice } \\
\text { Number of enquiries answer changed } \\
\text { patient management } \\
\text { Action taken as a result of MI answer } \\
\text { Number of enquiries were waiting for MI } \\
\text { answer before going ahead }\end{array}$ \\
\hline
\end{tabular}




\begin{tabular}{|c|c|c|c|c|c|c|c|c|c|}
\hline $\begin{array}{l}\text { Study } \\
\text { author } \\
\text { (Year) }\end{array}$ & Country & $\begin{array}{c}\text { Aim \& } \\
\text { objectives }\end{array}$ & $\begin{array}{l}\text { Study } \\
\text { participants }\end{array}$ & $\begin{array}{l}\text { Study } \\
\text { design }\end{array}$ & Duration & Sampling & Method & $\begin{array}{l}\text { Number of } \\
\text { participants } \\
\text { /enquiries } \\
\text { Response rate } \\
\text { where } \\
\text { appropriate }\end{array}$ & Outcome measure(s) \\
\hline & & $\begin{array}{l}\text { information } \\
\text { provided } \\
\text { If had a direct } \\
\text { impact on } \\
\text { outcome } \\
\text { Proportion of } \\
\text { enquiries were } \\
\text { clinician waiting } \\
\text { for answer before } \\
\text { proceeding } \\
\text { Minimum } \\
\text { expected level of } \\
\text { clinician uptake of } \\
\text { MI answers } \\
\end{array}$ & & & & & & & $\begin{array}{l}\text { Number of patients whose clinical outcome } \\
\text { differed compared to expected }\end{array}$ \\
\hline $\begin{array}{l}\text { McEntee } \\
\text { et al } \\
(2010)\end{array}$ & UK & $\begin{array}{l}\text { To assess how MI } \\
\text { answers were } \\
\text { used by clinicians } \\
\text { and usefulness in } \\
\text { patient care }\end{array}$ & $\begin{array}{l}\text { Clinicians in } \\
\text { primary and } \\
\text { secondary } \\
\text { care }\end{array}$ & $\begin{array}{l}\text { Prospective } \\
\text { Single site }\end{array}$ & 6 months & $\begin{array}{l}\text { Patient- } \\
\text { specific } \\
\text { enquiries }\end{array}$ & $\begin{array}{l}\text { Postal/ email } \\
\text { questionnaire }\end{array}$ & $\begin{array}{l}459 / 672 \\
\text { (68\% response } \\
\text { rate) }\end{array}$ & $\begin{array}{l}\text { How MI advice was used } \\
\text { Use in patient care }\end{array}$ \\
\hline $\begin{array}{l}\text { Innes } \\
\text { et al } \\
(2014)\end{array}$ & UK & $\begin{array}{l}\text { To determine the } \\
\text { impact of MI } \\
\text { advice on patient } \\
\text { care and } \\
\text { outcomes }\end{array}$ & $\begin{array}{l}\text { Clinicians in } \\
\text { primary and } \\
\text { secondary } \\
\text { care }\end{array}$ & $\begin{array}{l}\text { Prospective } \\
\text { Multicentre } \\
\text { ( } n=62) \\
\text { (33\% of UK } \\
\text { MI centres) }\end{array}$ & $\begin{array}{l}\text { Unclear- } \\
\text { max } 8 \\
\text { weeks? }\end{array}$ & $\begin{array}{l}\text { Patient- } \\
\text { specific } \\
\text { enquiries }\end{array}$ & $\begin{array}{l}\text { Two online } \\
\text { questionnaires } \\
\text { with a 5-point } \\
\text { rating scale } \\
\text { about impact of } \\
\text { MI advice on } \\
\text { patient care \& } \\
\text { outcomes } \\
1^{\text {st }} \text { questionnaire } \\
\text { completed by MI } \\
\text { centre at the } \\
\text { time of the } \\
\text { enquiry } \\
2^{\text {nd }} \text { questionnaire } \\
\text { emailed to } \\
\text { enquirer }\end{array}$ & $\begin{array}{l}647 / 1450 \\
\text { (45\% response } \\
\text { rate) }\end{array}$ & $\begin{array}{l}\text { Use of MI answer } \\
\text { Impact of MI answer on patient specific } \\
\text { measures using a rating scale i.e. ADRs; } \\
\text { Safety/risk; Patient concerns; Information } \\
\text { provided; Patient understanding; Choice of } \\
\text { medicines } \\
\text { Ability to explain risks/benefits to patient } \\
\text { Overall impact of MI answer on patient } \\
\text { care and outcomes }\end{array}$ \\
\hline
\end{tabular}




\begin{tabular}{|c|c|c|c|c|c|c|c|c|c|}
\hline $\begin{array}{l}\text { Study } \\
\text { author } \\
\text { (Year) }\end{array}$ & Country & $\begin{array}{c}\text { Aim \& } \\
\text { objectives }\end{array}$ & $\begin{array}{l}\text { Study } \\
\text { participants }\end{array}$ & $\begin{array}{l}\text { Study } \\
\text { design }\end{array}$ & Duration & Sampling & Method & $\begin{array}{l}\text { Number of } \\
\text { participants } \\
\text { /enquiries } \\
\text { Response rate } \\
\text { where } \\
\text { appropriate }\end{array}$ & Outcome measure(s) \\
\hline & & & & & & & $\begin{array}{l}\text { Expert panel } \\
\text { assessed a } \\
\text { random sample } \\
\text { of answers } \\
\text { (24/40) using a } 6 \\
\text { point rating scale }\end{array}$ & & \\
\hline $\begin{array}{c}\text { Bramley } \\
\text { et al } \\
(2013)\end{array}$ & UK & $\begin{array}{l}\text { To determine the } \\
\text { impact of MI } \\
\text { advice on patient } \\
\text { care and } \\
\text { outcomes }\end{array}$ & $\begin{array}{l}\text { Clinicians in } \\
\text { primary and } \\
\text { secondary } \\
\text { care }\end{array}$ & $\begin{array}{l}\text { Prospective } \\
\text { Multicentre } \\
\text { ( } n=35 \text { centres } \\
\text { in } 3 \text { regions in } \\
\text { England) }\end{array}$ & $\begin{array}{l}\text { Unclear- } \\
\text { max } 8 \\
\text { weeks? }\end{array}$ & $\begin{array}{l}\text { Patient- } \\
\text { specific } \\
\text { enquiries }\end{array}$ & $\begin{array}{l}\text { Two online- } \\
\text { questionnaires } \\
\text { completed } 2 \\
\text { weeks apart from } \\
\text { generation of } \\
\text { enquiry. Survey } \\
\text { included a 5-point } \\
\text { rating scale about } \\
\text { impact of MI } \\
\text { advice on patient } \\
\text { care /outcomes } \\
\text { Expert panel } \\
\text { assessed a } \\
\text { purposive sample } \\
\text { (20/24) of } \\
\text { answers using a } 6 \\
\text { point rating scale } \\
\text { Lead investigator } \\
\text { assessed all } \\
\text { answers using the } \\
\text { same } 6 \text { point } \\
\text { rating scale }\end{array}$ & $\begin{array}{l}\text { Unclear how } \\
\text { many clinicians } \\
\text { were initially } \\
\text { recruited } \\
316 \text { sent } 1 \text { st } \\
\text { questionnaire } \\
179 \text { responses } \\
\text { after } 2^{\text {nd }} \\
\text { questionnaire } \\
(57 \% \text { response } \\
\text { rate) }\end{array}$ & $\begin{array}{l}\text { Were they waiting for MI advice before } \\
\text { going ahead } \\
\text { Planned action after had MI answer } \\
\text { Action taken after MI answer } \\
\text { Rating scale to measure impact on patient } \\
\text { care and outcomes }\end{array}$ \\
\hline $\begin{array}{c}\text { Strobach } \\
\text { et al } \\
(2015)\end{array}$ & Germany & $\begin{array}{l}\text { To study the } \\
\text { impact of MIS on } \\
\text { clinical decision } \\
\text { making }\end{array}$ & $\begin{array}{l}\text { Doctors in } \\
\text { secondary } \\
\text { care }\end{array}$ & $\begin{array}{l}\text { Prospective } \\
\text { Single site }\end{array}$ & 12 months & $\begin{array}{l}\text { Patient- } \\
\text { specific drug- } \\
\text { drug } \\
\text { interaction } \\
\text { (DDI) } \\
\text { enquiries } \\
\text { answered in } \\
\text { writing } \\
\text { w }\end{array}$ & $\begin{array}{l}\text { Structured } \\
\text { telephone } \\
\text { interviews } \\
\text { Interviewed } 3 \text { to } \\
60 \text { days after } \\
\text { answer provided }\end{array}$ & $\begin{array}{l}113 / 127 \\
\text { (89\% response } \\
\text { rate) }\end{array}$ & All actions taken after MI answer \\
\hline
\end{tabular}




\begin{tabular}{|c|c|c|c|c|c|c|c|c|c|}
\hline $\begin{array}{l}\text { Study } \\
\text { author } \\
\text { (Year) }\end{array}$ & Country & $\begin{array}{c}\text { Aim \& } \\
\text { objectives }\end{array}$ & $\begin{array}{l}\text { Study } \\
\text { participants }\end{array}$ & $\begin{array}{l}\text { Study } \\
\text { design }\end{array}$ & Duration & Sampling & Method & $\begin{array}{l}\text { Number of } \\
\text { participants } \\
\text { /enquiries } \\
\text { Response rate } \\
\text { where } \\
\text { appropriate }\end{array}$ & Outcome measure(s) \\
\hline $\begin{array}{l}\text { Rutter } \\
\text { et al } \\
(2015)\end{array}$ & UK & $\begin{array}{l}\text { Explore the impact } \\
\text { MI advice had on } \\
\text { primary care } \\
\text { prescriber decision } \\
\text { making }\end{array}$ & $\begin{array}{l}\text { Doctors and } \\
\text { dentists in } \\
\text { primary care }\end{array}$ & $\begin{array}{l}\text { Prospective } \\
\text { Multicentre } \\
\text { ( } n=8 \text { regional } \\
\text { MI centres) }\end{array}$ & 6 Months & $\begin{array}{l}\text { Patient } \\
\text { specific } \\
\text { enquiries from } \\
\text { primary care } \\
\text { doctors and } \\
\text { dentists }\end{array}$ & $\begin{array}{l}\text { Semi-structured } \\
\text { telephone } \\
\text { interviews } \\
\text { Interviewed } 14 \text { to } \\
77 \text { days after } \\
\text { advice provided }\end{array}$ & $\begin{array}{l}37 \text { prescribers } \\
\text { generating } 40 \\
\text { interviews ( } 3 \\
\text { interviews } \\
\text { conducted with } \\
\text { repeat doctor } \\
\text { callers) }\end{array}$ & $\begin{array}{l}\text { No specific measures pre-determined due } \\
\text { to inductive nature of data analysis }\end{array}$ \\
\hline $\begin{array}{c}\text { Badiani } \\
\text { et al } \\
(2017)\end{array}$ & UK & $\begin{array}{l}\text { Did patients follow } \\
\text { advice given after } \\
\text { contacting an MI } \\
\text { patient helpline }\end{array}$ & $\begin{array}{l}\text { Patients and } \\
\text { carers }\end{array}$ & $\begin{array}{l}\text { Prospective } \\
\text { Single site }\end{array}$ & 9 months & $\begin{array}{l}\text { All callers } \\
\text { included until } \\
100 \text { surveys } \\
\text { were received }\end{array}$ & Questionnaire & $\begin{array}{l}100 / 157 \\
\text { (64\% response } \\
\text { rate) }\end{array}$ & Patient outcome after using helpline \\
\hline $\begin{array}{c}\text { Bramley } \\
\text { et al } \\
(2018)\end{array}$ & UK & $\begin{array}{l}\text { Assess patient } \\
\text { experience, } \\
\text { satisfaction and } \\
\text { outcomes after } \\
\text { contacting patient } \\
\text { helpline }\end{array}$ & Patients & $\begin{array}{l}\text { Prospective } \\
\text { Multicentre } \\
(n=2)\end{array}$ & $\begin{array}{l}4 \text { to } 6 \\
\text { weeks }\end{array}$ & All callers & $\begin{array}{l}\text { Questionnaire } \\
\text { Expert panel } \\
\text { assessed a } \\
\text { sample of } \\
\text { enquiries using } 2 \\
\text { rating scales: } \\
\text { patient } \\
\text { care/outcome and } \\
\text { medicines safety } \\
\\
\text { Delphi technique } \\
\text { with focus groups } \\
\text { to validate scales }\end{array}$ & $\begin{array}{l}67 / 111 \\
(60 \% \\
\text { response rate) }\end{array}$ & $\begin{array}{l}\text { Patient outcome after using helpline } \\
\text { Development and validation of impact } \\
\text { rating scale }\end{array}$ \\
\hline
\end{tabular}


Table 3: Study characteristics

\begin{tabular}{|c|c|c|c|}
\hline Category & & $\begin{array}{l}\mathrm{N} \\
\text { value }\end{array}$ & Authors \\
\hline \multirow[t]{3}{*}{$\begin{array}{l}\text { Geographic } \\
\text { area }\end{array}$} & $\begin{array}{l}\text { North } \\
\text { America }\end{array}$ & 5 & $\begin{array}{l}\text { Cardoni \& Thompson, 1978; Golightly et al., 1988; } \\
\text { Kinky et al., 1999; Marrone \& Heck, 2000; Melnyk et } \\
\text { al., } 2000\end{array}$ \\
\hline & UK & 9 & $\begin{array}{l}\text { Badiani et al., 2017; Bramley et al., 2009; Bramley et } \\
\text { al., 2013; Bramley 2018; Innes et al., 2014; Joseph \& } \\
\text { James, 2004; McEntee et al., 2010; Stubbington et al., } \\
\text { 1998; Rutter et al., } 2015\end{array}$ \\
\hline & Europe & 6 & $\begin{array}{l}\text { Bertsche et al., 2007; Frost Widnes \& Schjøtt, 2009; } \\
\text { Hedegaard \& Damkier, 2009; Maywald et al., 2004; } \\
\text { Schjøtt et al., 2002; Strobach et al., } 2015\end{array}$ \\
\hline \multirow[t]{2}{*}{$\begin{array}{l}\text { Publication } \\
\text { year }\end{array}$} & $1978-2009$ & 10 & $\begin{array}{l}\text { Bertsche et al., 2007; Cardoni \& Thompson, 1978; } \\
\text { Golightly et al., 1988; Kinky et al., 1999; Marrone \& } \\
\text { Heck, 2000; Melnyk et al., 2000; Stubbington et al., } \\
\text { 1998; Kinky et al., 1999; Marrone \& Heck, 2000; } \\
\text { Schjøtt et al., } 2002\end{array}$ \\
\hline & Post 2009 & 10 & $\begin{array}{l}\text { Badiani et al., 2017; McEntee et al., 2010; Frost } \\
\text { Widnes \& Schøøt, 2009; Strobach et al., 2015; } \\
\text { Bramley et al., 2009; Bramley et al., 2013; Bramley } \\
\text { 2018; Innes et al., 2014; Joseph \& James, 2004; } \\
\text { Rutter et al., } 2015\end{array}$ \\
\hline \multirow[t]{4}{*}{$\begin{array}{l}\text { Type of } \\
\text { study }\end{array}$} & Survey & 12 & $\begin{array}{l}\text { Badiani et al., 2017; Bramley et al., 2013; Bramley } \\
\text { 2018; Bertsche et al., 2007; Frost Widnes \& Schjøtt, } \\
\text { 2009; Hedegaard \& Damkier, 2009; Innes et al., 2014; } \\
\text { Joseph \& James, 2004; McEntee et al., 2010; } \\
\text { Maywald et al., 2004; Schjøtt et al., 2002; Stubbington } \\
\text { et al., 1998; }\end{array}$ \\
\hline & Interview & 5 & $\begin{array}{l}\text { Bramley et al., 2009; Cardoni \& Thompson, 1978; } \\
\text { Melnyk et al., 2000; Rutter et al., 2015; Strobach et } \\
\text { al., } 2015\end{array}$ \\
\hline & Cost analysis & 2 & Kinky et al., 1999; Marrone \& Heck, 2000 \\
\hline & Audit & 1 & Golightly et al., 1988 \\
\hline \multirow[t]{5}{*}{$\begin{array}{l}\text { Nature of } \\
\text { study }\end{array}$} & Prospective & 16 & $\begin{array}{l}\text { Badiani et al., 2017; Bertsche et al., 2007; Bramley et } \\
\text { al., 2009; Bramley et al., 2013; Bramley } \\
\text { 2018; Hedegaard \& Damkier, 2009; McEntee et al., } \\
\text { 2010; Maywald et al., 2004; Melnyk et al., 2000; Kinky } \\
\text { et al., 1999; Marrone \& Heck, 2000; Frost Widnes \& } \\
\text { Schjøtt, 2009; Strobach et al., 2015; Innes et al., } \\
\text { 2014; Joseph \& James, 2004; Rutter et al., } 2015\end{array}$ \\
\hline & Retrospective & 4 & $\begin{array}{l}\text { Cardoni \& Thompson, 1978; Golightly et al., 1988; } \\
\text { Kinky et al., 1999; Schjøtt et al., 2002; }\end{array}$ \\
\hline & Single centre & 14 & $\begin{array}{l}\text { Badiani et al., 2017; Bertsche et al., 2007; Cardoni \& } \\
\text { Thompson, 1978; Golightly et al., 1988; Hedegaard \& } \\
\text { Damkier, 2009; Joseph \& James, 2004; Kinky et al., } \\
\text { 1999; McEntee et al., 2010; Marrone \& Heck, 2000; } \\
\text { Maywald et al., 2004; Melnyk et al., 2000; Schjøtt et al., } \\
\text { 2002; Strobach et al., 2015; Stubbington et al., } 1998\end{array}$ \\
\hline & Multi-centre & 6 & $\begin{array}{l}\text { Bramley et al., 2009; Bramley et al., 2013; Bramley } \\
\text { 2018; Frost Widnes \& Schjøtt, 2009; Innes et al., } \\
\text { 2014; Rutter et al., } 2015\end{array}$ \\
\hline & Clinician & 14 & $\begin{array}{l}\text { Bertsche et al., 2007; Bramley et al., 2009; Bramley et } \\
\text { al., 2013; Cardoni \& Thompson, 1978; Frost Widnes \& }\end{array}$ \\
\hline
\end{tabular}




\begin{tabular}{|c|c|c|c|}
\hline \multirow[t]{3}{*}{$\begin{array}{l}\text { Population } \\
\text { under } \\
\text { study }\end{array}$} & & & $\begin{array}{l}\text { Schjøtt, 2009; Hedegaard \& Damkier, 2009; Innes et } \\
\text { al., 2014; Kinky et al., 1999; McEntee et al., 2010; } \\
\text { Marrone \& Heck, 2000; Rutter et al., 2015; Schjøtt et } \\
\text { al., 2002; Strobach et al., 2015; Stubbington et al., } \\
1998\end{array}$ \\
\hline & Public/patient & 4 & $\begin{array}{l}\text { Bramley 2018; Badiani et al., 2017; Joseph \& James, } \\
\text { 2004; Maywald et al., } 2004\end{array}$ \\
\hline & Both & 1 & Melnyk et al., 2000 \\
\hline \multirow{3}{*}{$\begin{array}{l}\text { Sector } \\
\text { where } \\
\text { clinician } \\
\text { worked }\end{array}$} & $\begin{array}{l}\text { Secondary } \\
\text { care }\end{array}$ & 4 & $\begin{array}{l}\text { Kinky et al., 1999; Marrone \& Heck, 2000; Strobach et } \\
\text { al., 2015; Stubbington et al., } 1998\end{array}$ \\
\hline & Primary care & 2 & Bertsche et al., 2007; Rutter et al., 2015 \\
\hline & Both sectors & 10 & $\begin{array}{l}\text { Bramley et al., 2009; Bramley et al., 2013; Cardoni \& } \\
\text { Thompson, 1978; Frost Widnes \& Schjøtt, 2009; ; } \\
\text { Golightly et al., 1988; Hedegaard \& Damkier, 2009; } \\
\text { Innes et al., 2014; McEntee et al., 2010; Melnyk et al., } \\
\text { 2000; Schjøtt et al., } 2002\end{array}$ \\
\hline
\end{tabular}

